\title{
Optinio neurito ryšys su išsėtine skleroze. Literatūros apžvalga
}

\section{A. Kubiliūté* \\ R. Liutkevičiené $\dot{x}^{* *}$ \\ *Lietuvos sveikatos mokslu universitetas, Medicinos akademija, Medicinos fakultetas}

**Lietuvos sveikatos mokslu universitetas, Neuromokslu institutas

\begin{abstract}
Santrauka. Optinio neurito ir išsėtinės sklerozės ryšys nagrinėjamas dẻl abi šias patologijas siejančių centrinẻje nervų sistemoje vyraujančių demielinizacijos ir neurodegeneracijos procesų. Tiek vienos, tiek kitos ligos atveju vyksta imuninio atsako sukeltas mielininio dangalo, o vẻliau ir aksonų, pažeidimas, lemiantis negrịžtamą neurologinių funkcijų sutrikimą. Šie procesai vyksta jauname amžiuje, todèl ankstyva ligos diagnostika ir jos suvaldymas turi reikšmės pacientų neurologinei funkcijai ir gyvenimo kokybei išsaugoti. Optinis neuritas gali pasireikšti kaip pirma išsėtinès sklerozès ataka, tad, tinkamai atpažinus jam būdingus simptomus ir nuodugniai ịvertinus oftalmologinès bei neurologinès patologijos požymius, patikimiausiais tyrimo metodais galima ne tik nustatyti regos sutrikimų priežastị, bet ir numatyti tikimybę susirgti išsètine skleroze. Deja, net ir išaiškinus, kad pacientas turi didelę riziką ateityje sirgti šia demielinizuojančia liga, nustačius optinị nervo uždegimą ar kitus išsėtinei sklerozei būdingus simptomus, priemonių sustabdyti ligos progresavimą kol kas nèra. Šiuo metu laikomasi principo ūmaus optinio neurito epizodui suvaldyti skirti intraveninius ir geriamuosius gliukokortikoidus, intraveninị imunoglobuliną, gydomąsias plazmaferezes. Tokio gydymo efektyvumas išlieka diskutuotinas, todèl tiriamos naujos medžiagos, kurių pritaikymas padètų apsaugoti nuo tolesnio nervinio audinio pažeidimo ir skatintų remielinizacijos procesus. Šiame straipsnyje aptariama optinio neurito epidemiologija, etiologija, patogenezè, pagrindiniai klinikos aspektai, diagnostikos bei gydymo galimybės ir ryšio su išsètinès sklerozės išsivystymu vertinimas.
\end{abstract}

Raktažodžiai: optinis neuritas, išsėtinė sklerozė, vienpusis regos sutrikimas, kliniškai izoliuotas sindromas.

\section{IVADAS}

Išsėtinè sklerozė (IS) - lètinė demielinizuojanti centrinès nervų sistemos liga, turinti imuninị komponentą, sukelianti neurologinių funkcijų sutrikimą jauno amžiaus pacientams [1]. Ja susergama 18-45 m. amžiuje ir apie $20 \%$ atvejų liga prasideda optinio neurito $(\mathrm{ON})$ simptomais - dažniausiai vienpusiu skausmingu regos sutrikimu ir sutrikusiu spalvų matymu, kuriuos lemia ūmus optinio nervo už- degimas ir demielinizacija [2, 3]. ON kilmè gali būti sąlygota ir kitų demielinizuojančių optinio neuromielito spektro ligų, sisteminių autoimuninių pažeidimų, infekcijų, toksinų poveikio, genetinių ligų [4]. Dažniausiai ON etiologija taip ir lieka neaiški, tačiau reikšmingu iššūkiu išlieka šių regos sutrikimų ryšio su IS nustatymas. Esant ON simptomams, svarbu įvertinti, ar yra kitų neurologinės klinikos išraiškų, diagnostinių tyrimų duomenų, leidžiančių patvirtinti IS. Jeigu regos sutrikimas yra vienintelis, izoliuotas laike požymis, jis potencialiai gali būti vertinamas kaip pirma IS ataka ir nustatomas kliniškai izoliuotas sindromas, kuri rekomenduojama nedelsiant gydyti imunomoduliuojančiais vaistais, siekiant kuo geresnių IS išeičių [5-7].

Šiame straipsnyje aptariama ON epidemiologija, etiologija, patogenezè, pagrindiniai klinikos aspektai, diagnostikos bei gydymo galimybès ir ryšio su IS išsivystymu vertinimas.

(C) Neurologijos seminarai, 2021. Open Access. This article is distributed under the terms of the Creative Commons Attribution 4.0 International License CC-BY 4.0 (http://creativecommons.org/licenses/by/4.0/), which permits unrestricted use, distribution, and reproduction in any medium, provided you give appropriate credit to the original author(s) and the source, provide a link to the Creative Commons license, and indicate if changes were made. 


\section{EPIDEMIOLOGIJA}

Moterys ON serga du kartus dažniau nei vyrai, ši liga labiau paplitusi tarp europiečių bei amerikiečių, būdingesnė baltaodžių rasei. Pagal vietovę, daugiau sergančiųjų yra tarp aukštutinių platumų gyventojų, o pagal metų laiką ON dažniausiai prasideda pavasarị [8-10]. Ryšys tarp ON ir sergamumo IS ịvairiose populiacijose skiriasi. Tačiau svarbu paminėti viename didžiausių optinio neurito tyrimų „Optical Neuritis Treatment Trial“ (ONTT) gautus rezultatus, kad tikimybė IS pasireikšti per 5 metus nuo pirmojo ON epizodo yra $30 \%$, o per 15 metų nuo izoliuotų ON simptomų pradžios ši tikimybė padidèja iki $50 \%$ [11].

\section{ETIOLOGIJA}

Optinis neuritas išsėtinės sklerozės metu stebimas $75 \%$ visų sergančiujjų, $20 \%$ atvejų - kaip pradinė ligos išraiška, tuomet jis vadinamas kliniškai izoliuotu sindromu. Ligos forma, kai regos sutrikimų priežastis yra IS, vadinama tipine, o atipinė siejama su platesne etiologija. Atipinį ON gali sukelti optinio neuromielito spektro ligos, sisteminès jungiamojo audinio ir kitos autoimuninès ligos, tokios kaip sisteminè raudonoji vilkligè, sarkoidozè, vaskulitai [9]. Infekcijos, sąlygotos B. burgdorferi, T. pallidum, $B$. henselae, įprastai žinomų kaip Laimo ligos, sifilio ir katès įdrèskimo ligos sukèlèjai, taip pat ir kitos infekcinès priežastys, priskiriamos atipinès formos etiologiniams veiksniams [12]. Nustatyta, kad atitinkamų žmogaus leukocitų antigeno alelių nešiojimas, pavyzdžiui, HLA DRB1*15, yra predisponuojantis veiksnys pasireikšti ON ir IS [13]. Taip pat tiriami ir kiti genetiniai veiksniai, kurių slopinimas ar aktyvavimas gali turèti reikšmės ON gydymui [14]. Kai daugeliu atvejų ON etiologija lieka neaiški, jis įvardijamas kaip idiopatinis [4].

\section{PATOFIZIOLOGIJA}

Tikslus patogenezinis $\mathrm{ON}$ mechanizmas nėra pakankamai ištirtas, tačiau manoma, kad regos sutrikimą sukelia du pagrindiniai procesai - uždegimas ir demielinizacija. Uždegiminị komponentą sudaro imuninio atsako aktyvuojami T limfocitai, kurie pereina kraujo ir smegenų barjerą ir, iš periferijos patekę i centrinę nervų sistemą, sukelia mielino destrukciją, aksonų degeneraciją ir neuronų žūtị. Šiuos procesus indukuoja atsipalaidavę citokinai ir kiti uždegimo mediatoriai, vyksta atidèta IV tipo hipersensityvinė reakcija [15]. Tai, kad uždegimo metu pažeidžiama ne tik baltoji medžiaga, įvertinama optinès koherentinès tomografijos tyrimu, kuriuo nustatomas tinklainès ganglinių ląstelių sluoksnio išplonėjimas, sukeltas aksonų pažaidos ir nykimo. Tokio pobūdžio degeneracinis procesas gali lemti sunkų ar negrižtamą regos funkcijos sutrikimą [16].

\section{KLINIKA}

Pacientams, sergantiems IS, yra būdingi skirtingi regos funkcijos sutrikimai, priklausomai nuo pažeistų nervinių skaidulų lokalizacijos. Tokie simptomai, kaip nesuderinti akių judesiai ir žvairumas, stebimi esant tarpbranduolinei oftalmoplegijai, kuri pasireiškia IS židiniams pažeidus galvos smegenų nervų branduolius ar išsivysčius atitraukiamojo, judinamojo akies nervų paralyžiui. Sakadiniai akių judesiai ir nistagmas atsiranda dèl smegenèlèse ar laiduose, jungiančiuose smegenėles su smegenų tiltu, vykstančių demielinizacijos procesų [17]. Tuo tarpu tipiniam ON būdingas ūmus ar poūmis, dažniau vienpusis regos sutrikimas, kuris pasireiškia pablogèjusiu regos aštrumu, besiliejančiu vaizdu, difuziniu ar lokalizuotu regos lauko iškritimu (dažnai centrinėmis skotomomis), sutrikusiu spalvų suvokimu (dischromatopsija) ir retroorbitaliniu skausmu ar skausmingais akių judesiais $[18,19]$. ON metu rega gali pablogèti per kelias valandas, ịprastai simptomai progresuoja iki savaitės [20]. Tačiau, atslūgus uždegimui, simptomai per kelias savaites nuo jų pasireiškimo pradžios pradeda mažèti ir apie $90 \%$ pacientų regos aštrumas pagerèja per vienerius metus [9]. ON yra būdinga vienfazė eiga, tačiau aprašoma atvejų, kai regos sutrikimas blogejja nenuosekliai, pasikartoja atkryčiai, kurių metu ligos simptomai atsinaujina ar pablogèja [21].

\section{DIAGNOSTIKA}

Esant ON klinikiniams požymiams, turi būti atliekama nuodugni oftalmologinè apžiūra regos nervo būklei įvertinti. Akių dugno netiesioginès biomikroskopijos metu stebima regos nervo disko edema, dažniausiai - vienpusè, atitinkamai toje akyje, kurioje pasireiškia simptomai. Tačiau šie požymiai nustatomi tik vienam trečdaliui pacientų, todèl visais atvejais rekomenduojama atlikti neinvazinị optinès koherentinės tomografijos (OKT) tyrimą, kuriuo identifikuojami tinklainės nervinių skaidulų sluoksniai ir įvertinamas jų storis [22]. OKT tyrimu gali būti nustatomas tinklainès ganglinių ląstelių ir nervinių skaidulų sluoksnio išplonėjimas, kuris atsiranda dèl uždegimo sukeltos aksonų demielinizacijos ir degeneracijos procesų [23, 24].

Nugaros smegenų skysčio tyrimas, diagnozuojant ON, rutiniškai neatliekamas, tačiau yra svarbus diferencinei diagnostikai, ypač tada, kai susiduriama su nebūdinga ON klinika - abipusiu regos sutrikimu, skausmo nebuvimu, simptomams pasireiškus $<18$ ar $>50 \mathrm{~m}$. amžiaus pacientams, kai galimos priežastys yra infekcinès, autoimuninès ar sukeltos optinio neuromielito spektro ligu $[25,26]$. Nugaros smegenų skystyje vertinamas limfocitų skaičius, baltymo kiekis, imunoglobulinas $\mathrm{G}$ ir oligokloninės grandinès, kurių radimas siejamas su rizika sirgti IS [27]. Verta paminèti regos sukeltų potencialų tyrimą, kuriuo, esant prailgejusiam potencialo atsakui, nustatoma optinio nervo aksonų demielinizacija. Svarbu tai, kad šis tyrimas turi prognostinę reikšmę regos funkcijai atsistatyti, kuri numa- 
toma pagal optinio nervo pažeidimo laipsni, vertinamą pakartotinai atliekant regos sukeltų potencialų tyrimą praejjus ūmiai ON fazei [28].

Vis tik, galvos smegenų ir akiduobių magnetinio rezonanso tomografija (MRT) išlieka pagrindiniu vaizdiniu tyrimu, siekiant patvirtinti ON diagnozę ir nustatyti IS išsivystymo tikimybę [29]. Atliekant MRT su kontrastu, stebimas optinio nervo orbitalinio segmento paburkimas ir signalo intensyvumo padidejimas T2 režimu ankstyvose ON stadijose bei kontrasto kaupimasis uždegimo srityje, kuris matomas daugiau nei $90 \%$ atvejų, jei tyrimas atliekamas per 3 sav. nuo simptomų pasireiškimo pradžios [30]. Tuo pačiu tyrimu nustačius kitus smegenų baltosios medžiagos pažeidimus, îvertinus jų skaičių, dydị, pasiskirstymą laike bei erdvėje ir šiems pažeidimams atitinkant McDonald kriterijus, patvirtinama ir IS diagnozė [31]. Net jeigu pradinio ištyrimo metu atliktoje smegenų MRT patologijos nestebima, IS išsivystymo tikimybė, praejus 15 metų, yra $25 \%$, o tiems pacientams, kuriems smegenų MRT tyrimu nustatyti demielinizuojantys pakitimai tuo metu ne visiškai atitinka IS diagnostinius kriterijus, pavyzdžiui, esant kliniškai izoliuotam sindromui, IS pasireiškimo tikimybẻ siekia $72 \%$ [11].

\section{GYDYMAS}

Pagrindiniai ON gydymo principai yra ūmaus epizodo suvaldymas ir palaikomojo gydymo taikymas. Ūmaus epizodo metu skiriant vaistus, tikimasi pasiekti greitesnio regos funkcijos atsistatymo ir atitolinti IS išsivystymą. Tam pasitelkiami gliukokortikoidai, intraveninis imunoglobulinas ir gydomosios plazmaferezès. Vartojant gliukokortikoidus, pirmenybè teikiama intraveniniam prednizolonui ir po jo taikomam palaikomajam geriamojo prednizolono kursui, kadangi, ONTT duomenimis, būtent tokia schema pagreitino regos funkcijos atsistatymą. Vèlesniuose tyrimuose statistiškai reikšmingas skirtumas tarp intraveninių ir geriamųjų steroidų poveikio regos pagerèjimui nenustatytas, juolab kad ir pačiame ONTT pastebėta, jog didesnio ilgalaikio poveikio regai atsistatyti, vartojant intravenini prednizoloną, lyginant su geriamuoju ar net placebu, nèra $[11,32]$. Bet kokiu atveju, vien geriamojo prednizolono skirti nerekomenduojama dèl ankstyvų ON atkryčių rizikos, kurie per 6 mèn. nuo šių vaistų vartojimo pradžios gali pasireikšti dvigubai dažniau, negu nevartojant jokių vaistų [33]. Dar viena ONTT pateikta išvada, kad intraveninio metilprednizolono vartojimas IS išsivystymą gali atitolinti dvejais metais, nebuvo patvirtinta vèliau atliktais tyrimais [34].

Intraveninio imunoglobulino (IVIG) skyrimas ūmioje ON fazèje gali nuslopinti uždegimą, pristabdyti demielinizaciją ir optinio nervo aksonų žūti, tačiau šie rezultatai nustatyti tyrimų su gyvūnais metu, todèl nėra pakankamai patikimi taikyti žmonių populiacijoje [35]. Nors yra ịrodymų, patvirtinančių, kad IVIG skyrimas turi teigiamą efektą, ypač tuomet, kai ON yra atsparus gydyti steroidais, vis tik sunku pasakyti, ar kiekvienu atveju bus pasiektas norimas rezultatas [36, 37]. Tuo tarpu gydymas plazmaferezėmis daugelyje šaltinių minimas kaip turintis teigiamą efektą tiek kaip sudètinè dalis po steroidų pulsterapijos, tiek sunkaus ON atvejais, nesant atsako ị gliukokortikoidus [38, 39].

Šiuo metu žinoma, kad tokios medžiagos, kaip memantinas, eritropoetinas, fenitoinas, turi neuroprotekcinių savybių, galinčių sulètinti tinklainès nervinių skaidulų sluoksnio plonėjimą ir optinio nervo aksonų žūtį, o tyrimų su gyvūnais metu nustatyta, kad, užblokavus LINGO-1 baltymą, kuris yra oligodendrocitu diferenciacijos ir remielinizacijos inhibitorius, pagerinami nervinio audinio atkūrimo procesai $[40,41]$. Veiksniai, stabdantys nervinio audinio degeneraciją ir skatinantys reparacinius procesus optinio neurito metu, pradèti tirti visai neseniai, tad vis dar reikalingi didesnès apimties tyrimai, kurie pagrịstų teigiamą jų poveiki. Vis dèlto, iki šiol atliktų tyrimų išvados teikia vilčių, kad imunomoduliaciniai ir neuroprotekciniai vaistai gali tapti nauja, efektyvia ON gydymo priemone.

ON gydymas turi būti apgalvotas dèl esančios rizikos ateityje išsivystyti IS. Kliniškai izoliuoto sindromo atveju, praejjus ūmiam epizodui, siekiant atitolinti kitų IS simptomų pasireiškimą ar išvengti ON atkryčių, galima skirti $\beta$-interferoną ir glatiramero acetatą. Pacientų grupeje, kuriems buvo skiriamas $\beta$-interferonas-1a ị raumenị ar po oda vieną kartą per savaitę ar glatiramero acetatas po oda kasdien, IS per dvejus metus pasireiškẻ 35-37 \% tiriamųjų, o placebo grupejje - 50-55 \% tiriamujų [6]. Taip pat interferoną vartojančių pacientų galvos smegenų MRT nustatyta mažiau IS židinių [42]. Identifikavus pacientus, kuriems nustatyti du ar daugiau pažeidimų galvos smegenų MRT, t. y. turinčius didelę riziką susirgti IS, ir paskyrus ligą modifikuojanti gydymą dar pirmo ON epizodo metu, per artimiausius 2-5 metus išvengiama neurologinių patologijų, sukeliančių negalią [43]. Deja, ilgalaikès šių pacientų išeitys, taikant ankstyvą ligą modifikuojanti gydymą, turimais duomenimis, nèra pakankamai išaiškintos.

\section{APIBENDRINIMAS}

Pacientams, sergantiems IS, yra būdingi ịvairūs neurologiniai simptomai, tarp jų ir regos funkcijos sutrikimas. Staigiu, vienpusiu, skausmingu regos aštrumo sumažėjimu, dischromatopsijomis, skotomomis pasižymi tipinis ON. Itariant šią patologiją, optinio nervo būklei ivvertinti svarbu atlikti nuodugnią oftalmologinę apžiūrą, optinès koherentinès tomografijos tyrimą. Kiti diagnostiniai testai, iš kurių svarbiausias yra galvos smegenų ir akiduobių MRT tyrimas, pasitelkiami diferencijuojant $\mathrm{ON}$ nuo kitų patologijų ir įvertinant IS požymius ar jų išsivystymo tikimybę. ON gydymas vis dar kelia nemažai klausimų ir i juos atsakyti reikalingi papildomi tyrimai, kurie pateiktų išvadas apie skirtingų medžiagų vartojimo poveikị nerviniam audiniui. Iki šiol vienas didžiausių ON gydymą nagrinėjančių tyrimų yra ONTT. Vis dèlto, šio tyrimo išvados išlieka kontroversiškos. 


\section{Literatūra}

1. Dobson R, Giovannoni G. Multiple sclerosis - a review. Eur J Neurol 2018; 26(1): 27-40. https://doi.org/10.1111/ ene. 13819

2. Wang I, Lin S, Woung L, Shih Y, Jou J. Clinical prospective study of visual function in patients with acute optic neuritis. J Formos Med Assoc 2013; 112(2): 87-92. https://doi.org/ 10.1016/j.jfma.2012.02.001

3. Arnold A. Evolving management of optic neuritis and multiple sclerosis. Am J Ophthalmol 2005; 139(6): 1101-8. https://doi.org/10.1016/j.ajo.2005.01.031

4. Kale N. Optic neuritis as an early sign of multiple sclerosis. Eye Brain 2016; 8: 195-202. https://doi.org/10.2147/ EB.S54131

5. Marcus J, Waubant E. Updates on clinically isolated syndrome and diagnostic criteria for multiple sclerosis. Neurohospitalist 2012; 3(2): 65-80. https://doi.org/10.1177/ 1941874412457183

6. Efendi H. Clinically isolated syndromes: clinical characteristics, differential diagnosis, and management. Noro Psikiyatr Ars 2015; 52(Suppl 1): S1-11. https://doi.org/10.5152/ npa.2015.12608

7. Marques I, Matias F, Silva E, Cunha L, Sousa L. Risk of multiple sclerosis after optic neuritis in patients with normal baseline brain MRI. J Clin Neurosci 2014; 21(4): 583-6. https://doi.org/10.1016/j.jocn.2013.06.013

8. The clinical profile of optic neuritis: Experience of the optic neuritis treatment trial. Arch Ophthalmol 1991; 109(12): 1673-8. https://doi.org/10.1001/archopht. 1991.01080120057025

9. Toosy A, Mason D, Miller D. Optic neuritis. Lancet Neurol 2014; 13(1): 83-99. https://doi.org/10.1016/S14744422(13)70259-X

10. Jin Y, de Pedro-Cuesta J, Söderström M, Stawiarz L, Link H. Seasonal patterns in optic neuritis and multiple sclerosis: a meta-analysis. J Neurol Sci 2000; 181(1-2): 56-64. https://doi.org/10.1016/S0022-510X(00)00408-1

11. The Optic Neuritis Study Group. Multiple sclerosis risk after optic neuritis: final optic neuritis treatment trial follow-up. Arch Neurol 2008; 65(6): 727-32. https://doi.org/10.1001/ archneur.65.6.727

12. Gaier ED, Boudreault K, Rizzo JF, 3rd, Falardeau J, Cestari DM. Atypical optic neuritis. Curr Neurol Neurosci Rep 2015; 15(12): 76. https://doi.org/10.1007/ s11910-015-0598-1

13. Tuwir I, Dunne C, Crowley J, Saddik T, Murphy R, Cassidy L. The relationship between HLA-DRB1 alleles and optic neuritis in Irish patients and the risk of developing multiple sclerosis. Br J Ophthalmol 2007; 91(10): 1288-92. https://doi.org/10.1136/bjo.2006.109371

14. Gedvilaite G, Vilkeviciute A, Kriauciuniene L, Asmoniene V, Liutkeviciene R. Does CETP rs5882, rs708272, SIRT1 rs12778366, FGFR2 rs2981582, STAT3 rs744166, VEGFA rs833068, IL6 rs1800795 polymorphisms play a role in optic neuritis development? Ophthalmic Genet 2019; 40(3): 219-26. https://doi.org/10.1080/13816810. 2019.1622022

15. Hoorbakht H. Optic neuritis, its differential diagnosis and management. Open Ophthalmol J 2012; 6(1): 65-72. https://doi.org/10.2174/1874364101206010065

16. Pau D, Al Zubidi N, Yalamanchili S, Plant G, Lee A. Optic neuritis. Eye 2011; 25(7): 833-42. https://doi.org/10.1038/ eye. 2011.81
17. Hoff JM, Dhayalan M, Midelfart A, Tharaldsen AR, Bø L. Visual dysfunction in multiple sclerosis. Tidsskr Nor Laegeforen 2019; 139(11). https://doi.org/10.4045/ tidsskr.18.0786

18. Bermel R, Balcer L. Optic neuritis and the evaluation of visual impairment in multiple sclerosis. Continuum (Minneap Minn) 2013; 19: 1074-86. https://doi.org/10.1212/01.CON. $0000433282.00221 .7 \mathrm{e}$

19. Nakajima H, Hosokawa T, Sugino M, Kimura F, Sugasawa J, Hanafusa T, et al. Visual field defects of optic neuritis in neuromyelitis optica compared with multiple sclerosis. BMC Neurol 2010; 10: 45. https://doi.org/10.1186/ 1471-2377-10-45

20. Caron-Cantin M, Cestari D, Fortin E. Clinical and radiologic approach to 'typical' versus antibody-related optic neuritis. Curr Opin Ophthalmol 2019; 30(6): 412-7. https://doi.org/ 10.1097/ICU.0000000000000614

21. Cellina M, Floridi C, Rosti C, Orsi M, Panzeri M, Pirovano M, et al. MRI of acute optic neuritis $(\mathrm{ON})$ at the first episode: can we predict the visual outcome and the development of multiple sclerosis (MS)? La radiologia medica 2019; 124(12): 1296-303. https://doi.org/10.1007/s11547019-01073-1

22. Margolin E. The swollen optic nerve: an approach to diagnosis and management. Pract Neurol 2019; 19(4): 302-9. https://doi.org/10.1136/practneurol-2018-002057

23. Britze J, Frederiksen J. Optical coherence tomography in multiple sclerosis. Eye 2018; 32(5): 884-8. https://doi.org/ 10.1038/s41433-017-0010-2

24. Britze J, Pihl-Jensen G, Frederiksen J. Retinal ganglion cell analysis in multiple sclerosis and optic neuritis: a systematic review and meta-analysis. J Neurol 2017; 264(9): 1837-53. https://doi.org/10.1007/s00415-017-8531-y

25. Kitley J, Waters P, Woodhall M, Leite M, Murchison A, George J, et al. Neuromyelitis optica spectrum disorders with aquaporin-4 and myelin-oligodendrocyte glycoprotein antibodies: a comparative study. JAMA Neurol 2014; 71(3): 276-83. https://doi.org/10.1001/jamaneurol. 2013.5857

26. Abel A, McClelland C, Lee M. Critical review: typical and atypical optic neuritis. Surv Ophthalmol 2019; 64(6): 770-9. https://doi.org/10.1016/j.survophthal.2019.06.001

27. Gelfand JM. Multiple sclerosis: diagnosis, differential diagnosis, and clinical presentation. Handb Clin Neurol 2014; 122: 269-90. https://doi.org/10.1016/B978-0-444-520012.00011-X

28. Leocani L, Guerrieri S, Comi G. Visual evoked potentials as a biomarker in multiple sclerosis and associated optic neuritis. J Neuroophthalmol 2018; 38(3): 350-7. https://doi.org/ 10.1097/WNO.0000000000000704

29. Soelberg K, Skejoe H, Grauslund J, Smith T, Lillevang S, Jarius $S$, et al. Magnetic resonance imaging findings at the first episode of acute optic neuritis. Mult Scler Relat Disord 2018; 20: 30-6. https://doi.org/10.1016/j.msard. 2017.12.018

30. Hoch M, Bruno M, Shepherd T. Advanced MRI of the optic nerve. J Neuroophthalmol 2017; 37(2): 187-96. https://doi.org/10.1097/WNO.0000000000000511

31. Polman C, Reingold S, Banwell B, Clanet M, Cohen J, Filippi M, et al. Diagnostic criteria for multiple sclerosis: 2010 revisions to the McDonald criteria. Ann Neurol 2011; 69(2): 292-302. https://doi.org/10.1002/ana.22366

32. Morrow S, Fraser J, Day C, Bowman D, Rosehart H, Kremenchutzky M, et al. Effect of treating acute optic neuri- 
tis with bioequivalent oral vs. intravenous corticosteroids. JAMA Neurol 2018; 75(6): 690. https://doi.org/10.1001/ jamaneurol.2018.0024

33. Wilhelm H, Schabet M. The diagnosis and treatment of optic neuritis. Dtsch Arztebl Int 2015; 112(37): 616-26. https://doi.org/10.3238/arztebl.2015.0616

34. Bennett J. Optic neuritis. Continuum (Minneap Minn) 2019; 25(5): 1236-64. https://doi.org/10.1212/CON. 0000000000000768

35. Takahashi H, Okuda S, Tamura M, Kamei S, Aizawa R, Kobayashi T. Prophylactic treatment with intravenous immunoglobulin attenuates experimental optic neuritis in mice. Biol Pharm Bull 2019; 42(2): 173-8. https://doi.org/ 10.1248/bpb.b18-00458

36. Roed H, Langkilde A, Sellebjerg F, Lauritzen M, Bang P, Mørup A, et al. A double-blind, randomized trial of IV immunoglobulin treatment in acute optic neuritis. Neurology 2005; 64(5): 804-10. https://doi.org/10.1212/01.WNL. 0000152873.82631.B3

37. Tselis A, Perumal J, Caon C, Hreha S, Ching W, Din M, et al. Treatment of corticosteroid refractory optic neuritis in multiple sclerosis patients with intravenous immunoglobulin. Eur J Neurol 2008; 15(11): 1163-7. https://doi.org/10.1111/ j.1468-1331.2008.02258.x

38. Song W, Qu Y, Huang X. Plasma exchange: an effective add-on treatment of optic neuritis in neuromyelitis optica spectrum disorders. Int Ophthalmol 2019; 39(11): 2477-83. https://doi.org/10.1007/s10792-019-01090-z

39. Roesner S, Appel R, Gbadamosi J, Martin R, Heesen C. Treatment of steroid-unresponsive optic neuritis with plasma exchange. Acta Neurol Scand 2011; 126(2): 103-8. https://doi.org/10.1111/j.1600-0404.2011.01612.x

40. Beisse F, Diem R. Immunmodulation und Neuroprotektion bei Neuritis nervi optici. Der Ophthalmologe 2016; 113(5): 398-401. https://doi.org/10.1007/s00347016-0264-2

41. Meltzer E, Prasad S. Updates and controversies in the management of acute optic neuritis. Asia Pac J Ophthalmol (Phila) 2018; 7(4): 251-6. https://doi.org/10.22608/ APO.2018108
42. Balcer L. Optic neuritis. N Engl J Med 2006; 354(12): 1273-80. https://doi.org/10.1056/NEJMcp053247

43. Miller D, Chard D, Ciccarelli O. Clinically isolated syndromes. Lancet Neurol 2012; 11(2): 157-69. https://doi.org/ 10.1016/S1474-4422(11)70274-5

\section{A. Kubiliūtė, R. Liutkevičienė \\ THE LINK BETWEEN OPTIC NEURITIS AND MULTIPLE SCLEROSIS. LITERATURE REVIEW}

\section{Summary}

Optic neuritis and multiple sclerosis are connected via processes of demyelination and neurodegeneration in the central nervous system. Immuno-modulated myelin sheathing and axonal loss causing irreversible neurological dysfunction can be found in both pathologies. Patients who experience these conditions are usually young adults, therefore early diagnosis and control of the disease may benefit in preserving their neurological function and quality of life. The first attack of multiple sclerosis often presents as optic neuritis which is important to distinguish based on appropriate clinical signs and evaluation of diagnostic features. Some diagnostic methods may not only help to understand the cause of vision loss, but also provide predictive value for the development of multiple sclerosis in the future. Unfortunately, no effective treatment to slow the progression of the disease has been approved yet. Intravenous and oral corticosteroids, intravenous immunoglobulin, and therapeutic plasmapheresis are used to manage acute episodes of optic neuritis; however, the effectiveness of such treatment is also debatable. Thereby, new substances are being researched recently to evaluate their significance in the processes of remyelination and neuroprotection. Some aspects of epidemiology, etiology, pathogenesis, clinical signs, possibilities of diagnosis and treatment of optic neuritis together with the evaluation of the risk of multiple sclerosis development are discussed in this article.

Keywords: optic neuritis, multiple sclerosis, unilateral vision loss, clinically isolated syndrome.

Gauta:

20201201

Priimta spaudai: 20210125 